\title{
Soybean yield in the Matopiba region under climate changes
}

\author{
Vicente de P. R. da Silva ${ }^{1}$, Roberta A. e Silva², Girlene F. Maciel ${ }^{2}$, Enio P. de Souza ${ }^{1}$, Célia C. Braga ${ }^{1}$ \& \\ Romildo M. de Holanda ${ }^{3}$ \\ ${ }^{1}$ Universidade Federal de Campina Grande. Campina Grande, PB, Brasil. E-mail: vicente.paulo@ufcg.edu.br (Corresponding author) - ORCID: 0000- \\ 0003-4914-4833; enio.souza@ufcg.edu.br - ORCID: 0000-0001-6154-398X; celia.braga@ufcg.edu.br - ORCID: 0000-0001-6383-3112 \\ ${ }^{2}$ Universidade Federal de Tocantins. Palmas, TO, Brasil. E-mail: roberta.as@mail.uft.edu.br - ORCID: 0000-0002-9682-3006; maciel@mail.uft.edu.br - \\ ORCID: 0000-0001-9217-3731 \\ ${ }^{3}$ Universidade Federal Rural de Pernambuco. Recife, PE, Brasil. E-mail: romildomorant@gmail.com - ORCID: 0000-0001-7945-3616
}

\begin{abstract}
The climatic conditions along the cycle are the main factors responsible for the final production of any crop. This study aimed to evaluate the current conditions and the effects of climate change scenarios on the yield of soybean grown in the Matopiba region, located between the states of Tocantins, south and northeast of Maranhão, south of Piauí and west of Bahia, Brazil. The AquaCrop model of FAO, version 5.0, was calibrated with data of 2014 and validated with those of 2016, using climate, soil and crop management parameters collected in two experimental campaigns conducted between June and October in 2014 and 2016 in Palmas, TO, Brazil. The performance of the model was evaluated using the following statistical indicators: prediction error $(\mathrm{PE})$, coefficient of determination $\left(\mathrm{R}^{2}\right)$, normalized root mean square error (NRMSE), NashSutcliffe model efficiency coefficient (EF) and Willmott's index of agreement (d). It was verified that the AquaCrop model underestimates soybean grain yield under severe water stress conditions throughout the growing cycle. The increase in $\mathrm{CO}_{2}$ concentration and in the air temperature, projected by the climate models HadGEM2-ES and MIROC5 under the scenario of stabilization (RCP 4.5) and the scenario of progression (RCP 8.5 ), have contributed to the increase in soybean yield by the end of this century.
\end{abstract}

Key words: Glycine max, yield, AquaCrop model, climate variability

\section{Produtividade da soja na região de Matopiba sob mudanças climáticas}

RESUMO: As condições climáticas durante o ciclo da cultura são os principais fatores responsáveis pela produção final de qualquer cultivo. Este estudo teve o objetivo de avaliar as condições atuais e os efeitos dos cenários de mudanças climáticas sobre a produtividade da soja cultivada na região de Matopiba, localizada entre os Estados do Tocantins, Sul e Nordeste do Maranhão, Sul do Piauí e Oeste da Bahia. O modelo AquaCrop, versão 5.0 da FAO foi calibrado com dados do ano de 2014 e validado com os de 2016 em Palmas, TO, usando parâmetros de clima, solo, manejo da cultura coletados em duas campanhas experimentais realizadas entre os meses de junho e outubro nos anos de 2014 e 2016 . O desempenho do modelo foi avaliado utilizando os indicadores estatísticos: erro de previsão (EP), coeficiente de determinação $\left(\mathrm{R}^{2}\right)$, raiz quadrada do erro médio normalizado (RMSEN), coeficiente de eficiência do modelo Nash-Sutcliffe (EF) e o índice de concordância de Willmott (d). Verificou-se que o modelo AquaCrop subestima a produtividade de grãos de soja, na condição de déficit hídrico severo durante todo o ciclo do cultivo. $\mathrm{O}$ aumento da concentração de $\mathrm{CO}_{2}$ e da temperatura, projetada pelos modelos climáticos HadGEM2-ES e MIROC5 sob o cenário de estabilização (RCP 4.5) e o cenário de progressão RCP 8.5, contribuem para o aumento da produtividade de soja até o final deste século.

Palavras-chave: Glycine max, produtividade, modelo AquaCrop, variabilidade climática 


\section{INTRODUCTION}

Grain production in the Matopiba region already represents $12.8 \%$ of the total production in Brazil, with soybean as the main grain and also the one with highest profitability, where much that is produced is intended for export. According to data from Brasil (2015), soybean production has significantly increased in the four states comprising the Matopiba region, with increments of $26.4 \%$ in Bahia, $23.1 \%$ in Piauí, $13.5 \%$ in Maranhão and 20.2\% in Tocantins, Brazil.

The possible climate changes projected for the $21^{\text {st }}$ century could significantly alter agricultural production, biodiversity and water resources, because with the warming evaporation will increase and water availability will decrease as the stored water is removed from the soil, generating a greater water deficit (Silva et al., 2018). Climate change can significantly alter crop production (FAO, 2012) because it will probably be accompanied by an increase in air temperature due to the increase in the concentration of carbon dioxide $\left(\mathrm{CO}_{2}\right)$, directly influencing the development, growth and yield of agricultural crops (Fagundes et al., 2010).

The capacity of the AquaCrop model (Raes et al., 2009; Steduto et al., 2009) to simulate the yield of different crops has been tested by several researchers worldwide: wheat in Siberia (Stricevic et al., 2011), cotton in the USA (Baumhardt et al., 2009), barley in Ethiopia (Araya et al., 2010); maize in Portugal (Paredes et al., 2015); soybean in Lebanon (Abi Saab et al., 2014) and in the Matopiba region, Brazil (Silva et al., 2018). In the context of the economic importance of soybean for the Matopiba region, it is imperative to conduct research studies addressing water use, taking into account the current pressure of agricultural practices on the water resources of this region through climate change scenarios.

Therefore, this study aimed to calibrate and validate the AquaCrop model in order to simulate the yield of the soybean cultivar TMG 1288RR adapted to the soil and climate conditions of the Matopiba region and to estimate the yield of this soybean cultivar for the conditions of current climate and future climate changes.

\section{Material ANd Methods}

The geographic region called MATOPIBA is an acronym resulting from the initial letters of the four states composing it: Maranhão, Tocantins, Piauí and Bahia, Brazil. The MATOPIBA area corresponds to the entire state of Tocantins, south and northeast of Maranhão, south of Piauí and west of Bahia.

The AquaCrop model, developed by FAO, focuses on the simulation modeling of growth and yield of herbaceous crops in response to water supplied by supplemental or full irrigation, water deficit or rainfed conditions, and other abiotic stresses (temperature, fertilization, salinity and $\mathrm{CO}_{2}$ ) (Steduto et al., 2012). The data for calibrating the AquaCrop model were obtained at the experimental station of the Universidade Federal de Tocantins, in Palmas, Brazil (10 $10^{\prime}$ S, $48^{\circ} 21^{\prime} \mathrm{W}$ and altitude of $216 \mathrm{~m}$ ).

The structural components of the AquaCrop model include soil (soil water balance), plant and atmosphere, which define the environment where the crop develops. The atmosphere and soil components used by AquaCrop model are similar to those of other known models of crop yield simulation; what distinguishes the AquaCrop model is the relationship between the plant and soil components. AquaCrop models the crop based on five main components (phenology/development, canopy cover, rooting depth, biomass production and yield), and its responses associated with water stress.

Dry above-ground biomass and the final yield were estimated by the AquaCrop model, referred to as a "waterdriven model", including the effect of water through Eqs. 1 and 2.

$$
\begin{gathered}
\mathrm{B}=\mathrm{WP} \sum \mathrm{T}_{\mathrm{r}} \\
\mathrm{Y}=\mathrm{B} \mathrm{HI}
\end{gathered}
$$

where:

$$
\begin{array}{ll}
\mathrm{WP} & \text { - water productivity, } \mathrm{kg} \mathrm{m}^{-2} \mathrm{~mm}^{-1} \text {; } \\
\mathrm{Tr} & \text { - crop transpiration, dimensionless; } \\
\mathrm{B} & \text { - Dry above-ground biomass, } \mathrm{kg} ; \\
\mathrm{Y} & \text { - final yield, } \mathrm{kg} \text {; and, } \\
\mathrm{HI} & \text { - harvest index, \%. }
\end{array}
$$

Further details of the methodological procedures of the AquaCrop model can be found in Silva et al. (2018). The AquaCrop model was calibrated and validated for the MATOPIBA geographic region using as input the daily data of the elements of climate (maximum and minimum air temperatures, maximum and minimum air relative humidity, rainfall, wind speed and solar radiation), crop, soil and field management collected from two field experiments, installed in the experimental area of the Universidade Federal de Tocantins (UFT), on the campus of Palmas, Brazil.

Both experimental campaigns were conducted in the dry season, one in 2014, between June 20 and October 15, and the other in 2016, between June 20 and October 21, totaling 117 DAP (days after planting) and 124 DAP, respectively. The dry season was chosen because of the need to control the entry of water into the soil through different irrigation depths during the period, in the absence or low levels of rainfall.

Climate elements were collected at the automatic weather station installed within the experimental area. The crop parameters considered were the conservative and nonconservative parameters of the soybean cultivar TMG $1288 \mathrm{RR}$, of late maturity cycle and adapted to the edaphoclimatic conditions of the Matopiba geographic region. Conservative parameters are those that do not change with geographic location, management practices and weather conditions, are applicable to various conditions and are not specific to a given cultivar.

Non-conservative parameters are specific to a given cultivar and are affected by the weather conditions, field management or conditions in the soil profile, being entered by the user in the AquaCrop model (Heng et al., 2009; Raes et al., 2009; Steduto et al., 2009). Management parameters were obtained by manual sowing of soybean (cv. TMG $1288 \mathrm{RR}$ ), with experimental design in randomized blocks with four repetitions, and the irrigation treatments were arranged in a split-plot scheme, in 
two subplots. The experimental area of each plot was $70 \mathrm{~m}^{2}(3.5$ $\mathrm{x} 20 \mathrm{~m})$, totaling an area of $610 \mathrm{~m}^{2}(30.5 \times 20 \mathrm{~m})$ occupied by the experiment, consisting of 56 planting rows and 14 plants per linear meter.

ET $_{\mathrm{o}}$ was estimated by the Penman-Monteith method (Allen et al., 1998), using ET software and Eq. 3.

$$
\mathrm{ET}_{\mathrm{o}}=\frac{0.408 \Delta(\mathrm{Rn}-\mathrm{G})+\gamma \frac{900}{\mathrm{~T}+273} \mathrm{u}_{2}\left(\mathrm{e}_{\mathrm{s}}-\mathrm{e}_{\mathrm{a}}\right)}{\Delta+\gamma\left(1+0.34 \mathrm{u}_{2}\right)}
$$

where:

$\mathrm{ET}_{\mathrm{o}}$ - reference evapotranspiration $\left(\mathrm{mm} \mathrm{d}^{-1}\right)$;

$\mathrm{Rn}$ - net radiation on the surface $\left(\mathrm{MJ} \mathrm{m}^{-2} \mathrm{~d}^{-1}\right)$;

$\mathrm{G}$ - soil heat flux $\left(\mathrm{MJ} \mathrm{m}^{-2} \mathrm{~d}^{-1}\right)$;

$\mathrm{T}$ - daily air temperature at $2 \mathrm{~m}$ height, ${ }^{\circ} \mathrm{C}$;

$\mathrm{U}_{2} \quad$ - wind speed at $2 \mathrm{~m}$ height, $\mathrm{m} \mathrm{s}^{-1}$;

$\mathrm{e}_{\mathrm{s}} \quad$ - saturation vapor pressure, $\mathrm{kPa}$;

$\mathrm{e}_{\mathrm{a}} \quad$ - actual vapor pressure, $\mathrm{kPa}$;

$\mathrm{e}_{\mathrm{s}}-\mathrm{e}_{\mathrm{a}}$ - vapor pressure deficit, $\mathrm{kPa}$;

$\Delta \quad$ - slope of the vapor pressure curve, $\mathrm{kPa}^{\circ} \mathrm{C}^{-1}$; and,

$\gamma \quad$ - psychrometric constant, $\mathrm{kPa}^{\circ} \mathrm{C}^{-1}$.

At harvest, the borders of each plot, two rows on the sides and $0.5 \mathrm{~m}$ of the ends of the rows were disregarded, resulting in a observation area of $3.6 \mathrm{~m}^{2}$ per experimental plot with a total of 112 plants. Cultural practices consisted of plowing and harrowing, soil correction, fertilization, application of formicide and fungicide and manual cleaning of the beds.

Drip irrigation was the method adopted, where each planting row had one polyethylene lateral line with nominal diameter of $16 \mathrm{~mm}$ containing drippers spaced by $0.5 \mathrm{~m}$. Irrigation was performed daily, applying seven irrigation depths referred to as T1, T2, T3, T4, T5, T6 and T7, from the highest to the lowest depth and varying according to the plant growth stages (Table 1).

Crop evapotranspiration $\left(\mathrm{ET}_{\mathrm{C}}\right)$ was determined by the product between crop coefficient $(\mathrm{Kc})$ and reference evapotranspiration $\left(\mathrm{ET}_{\mathrm{o}}\right)$, i.e., $\mathrm{ET}_{\mathrm{c}}=\mathrm{Kc} \mathrm{ET}_{\mathrm{o}}$.

Future time simulations of the main soybean-producing municipalities of the Matopiba geographic area were obtained through meteorological data series generated by the Global Climate Models (GCM), used to project future climate changes by simulating different scenarios.

The main soybean-producing municipalities in Matopiba region are: Balsas - MA, Campos Lindos, TO, Baixa Grande do Ribeiro, PI and Formosa do Rio Preto, BA, Brazil. The British model

Table 1. Irrigation treatments applied to the soybean crop cultivated in Palmas, TO, Brazil, as a function of crop evapotranspiration (ET)

\begin{tabular}{cl}
\hline Treatment & \multicolumn{1}{c}{ Irrigation depth } \\
\hline $\mathrm{T} 1$ & $25 \% \mathrm{ET}_{\mathrm{c}} \mathrm{TC}$ \\
$\mathrm{T} 2$ & $100 \% \mathrm{ET}_{\mathrm{c}}$ at $\mathrm{VS}$ and $25 \% \mathrm{ET}_{\mathrm{c}}$ at $\mathrm{RS}$ \\
$\mathrm{T} 3$ & $50 \% \mathrm{ET}_{\mathrm{c}} \mathrm{TC}$ \\
$\mathrm{T} 4$ & $100 \% \mathrm{ET}_{\mathrm{c}}$ at $\mathrm{VS}$ and $50 \% \mathrm{ET}_{\mathrm{c}}$ at $\mathrm{RS}$ \\
$\mathrm{T} 5$ & $25 \% \mathrm{ET}_{\mathrm{c}}$ at $\mathrm{VS}$ and $100 \% \mathrm{ET}_{\mathrm{c}}$ at RS \\
$\mathrm{T} 6$ & $50 \% \mathrm{ET}_{\mathrm{c}}$ at VS and $100 \% \mathrm{ET}_{\mathrm{c}}$ at RS \\
$\mathrm{T} 7$ & $100 \% \mathrm{ET}_{\mathrm{c}} \mathrm{TC}$ \\
\hline
\end{tabular}

TC - Throughout the cycle; VS - Vegetative stage; RS - Reproductive stage
HadGEM2-ES (Met Office Hadley Center, $1.875^{\circ} \times 1.25^{\circ}$ ) (Bellouin et al., 2011) and the Japanese model MIROC5 (Center for Climate System Research - CCSR; University of Tokyo; National Institute for Environmental Studies - NIES) were used. The advantage of using regional climate models is the possibility of detailing the results of global models with a relatively low computational cost. Current and future daily climatic values, reduced for the study site (downscaling), were produced using the MarkSimGCM, which is a thirdorder Markov rainfall generator that was not designed for this purpose, but has been used efficiently as temporal and spatial downscaling, with a resolution of $0.5^{\circ}$ (approximately $50 \mathrm{~km}$ )

To evaluate the impact of climate change with and without adaptation strategies in the future, climate change scenarios, the Representative Concentration Pathways (RCP) of the IPCC Fifth Assessment Report (IPCC, 2014) were selected. The scenarios of RCP 4.5 and RCP 8.5 are respectively considered scenarios of stabilization (optimistic) and progression (pessimistic) of the emission of greenhouse gases.

The annual concentrations of $\mathrm{CO}_{2}$ for the current and future periods were obtained in the climate component database of AquaCrop 5.0 model, which is able to simulate yield for high temperatures and $\mathrm{CO}_{2}$ concentrations. The yields of future scenarios in the medium term (2045/2046 and 2055/2056) and in the long term (2075/2076 and 2094/2095), for the selected soybean-producing municipalities of the Matopiba, were generated for each model and scenario.

The performance of the AquaCrop model was evaluated by comparing its results with the observed data of yield obtained at harvest. In this step, the following statistical indices were used (Eqs. 4 to 7 ):

(i) Normalized root mean square error (NRMSE, $\left.\mathrm{t} \mathrm{ha}^{-1}\right)$ :

$$
\mathrm{NRMSE}=\frac{1}{\overline{\mathrm{O}}} \sqrt{\frac{\sum(\mathrm{Si}-\mathrm{Oi})^{2}}{\mathrm{n}}} 100
$$

(ii) Willmott's index of agreement (d):

$$
\mathrm{d}=1-\frac{\sum_{\mathrm{i}-1}^{\mathrm{n}}\left(\mathrm{S}_{\mathrm{i}}-\mathrm{O}_{\mathrm{i}}\right)^{2}}{\sum\left|\mathrm{S}_{\mathrm{i}}-\mathrm{O}_{\mathrm{i}}\right|+\left|\mathrm{O}_{\mathrm{i}}-\overline{\mathrm{O}_{\mathrm{i}}}\right|}
$$

(iii) Nash-Sutcliffe model efficiency coefficient (EF):

$$
\mathrm{EF}=10 \frac{\sum(\mathrm{Si}-\mathrm{Oi})^{2}}{\sum\left(\mathrm{Si}-\overline{\mathrm{O})^{2}}\right.}
$$

(iv) Prediction error (PE):

$$
\mathrm{PE}=\frac{\sum(\mathrm{Si}-\mathrm{Oi})}{\left(\sum \mathrm{Oi}\right)} 100
$$

where:

Si and Oi - simulated and observed data, respectively;

$\overline{\mathrm{Oi}}$ - mean value of Oi; and,

n - number of observations. 
When EF and d are close to one and PE and NRMSE are close to $0 \%$, these indices indicate positive performance of the model. The simulation is considered excellent if RMSEN is less than $10 \%$; that is, good if it is from 10 to $20 \%$; reasonable when it is from $20 \%$ to $30 \%$; and bad when it is above $30 \%$.

\section{Results AND Discussion}

According to Table 2, which presents soybean grain yields observed and simulated by the AquaCrop model and the Prediction Error (PE) for different irrigation depths, there was a good fit in the calibration between the observed and AquaCrop-simulated grain yields, with a slight trend of underestimation in the treatments $\mathrm{T} 1$ and $\mathrm{T} 3$, with negative deviations of 10.9 and $27.5 \%$, respectively.

The simulated grain yields ranged from 1.12 to $3.45 \mathrm{t} \mathrm{ha}^{-1}$ while the observed yield varied between 1.26 and $3.46 \mathrm{t} \mathrm{ha}^{-1}$. It is noted that for calibration, the maximum and the minimum prediction errors of simulated grain yield were observed for the treatments T3 and T5, respectively, with values of -27.5 and $0.04 \%$. In addition, better fit of the model was found for the treatment $\mathrm{T} 5$, which received $25 \%$ ETc in the vegetative stage and $100 \%$ ETc in the reproductive stage. The worst fit was verified for the treatment $\mathrm{T} 3$, which received $50 \%$ ETC throughout the cycle.

Regarding the AquaCrop validation, the simulated soybean yields varied from $1.04 \mathrm{t} \mathrm{ha}^{-1}$, for the treatment $\mathrm{T} 1 \mathrm{under}$ severe water deficit, to $3.77 \mathrm{t} \mathrm{ha}^{-1}$, for the treatment $\mathrm{T} 7$ without water deficit. The prediction error ranged from a minimum of $-0.9 \%$ for the treatment $\mathrm{T} 3$, which received $50 \% \mathrm{ET}_{\mathrm{c}}$ throughout the cycle, to a maximum of $8.33 \%$ for the treatment $\mathrm{T} 1$, which received only $25 \% \mathrm{ET}_{\mathrm{c}}$ throughout the cycle (Table 1 ).

The prediction error statistics of the calibration and validation of the AquaCrop model for all irrigation treatments along the soybean cultivation cycle are presented in Table 3. By analyzing the performance of the model to estimate yield, it was possible to observe that it showed excellent precision $\left(R^{2}=0.90 ; d=0.98\right)$ with the yield observed in the field experiment.

The $\mathrm{R}^{2}$ value indicates that the model explained $90 \%$ of the variation between the observed and simulated yields, while the index $d$ close to 1 indicates that AquaCrop model was able to simulate soybean yield with a high degree of reliability. Similar values have been found by Araya et al. (2010) with $\mathrm{R}^{2}=0.80$, Stricevic et al. (2011) with $\mathrm{R}^{2}=0.84$, Karunaratne et al. (2011) with $\mathrm{R}^{2}=0.72$ and Abedinpour et al. (2012) with $\mathrm{R}^{2}=0.99$.

The values of the errors NRMSE $=0.24 \mathrm{t} \mathrm{ha}^{-1}$ and $\mathrm{d}=0.98$, which respectively represent 11 and $5 \%$ of the mean yield
Table 3. Prediction error statistics for the calibration and validation of the AquaCrop model for all irrigation treatments

\begin{tabular}{|c|c|c|c|c|c|c|}
\hline \multirow{2}{*}{$\begin{array}{l}\text { Model output } \\
\text { parameter }\end{array}$} & \multicolumn{2}{|c|}{ Mean } & \multirow{2}{*}{$\mathbf{R}^{2}$} & \multirow{2}{*}{$\begin{array}{l}\text { NRMSE } \\
\left(\mathrm{t} \mathrm{ha}^{-1}\right)\end{array}$} & \multirow{2}{*}{ EF } & \multirow{2}{*}{ d } \\
\hline & Observed & Simulated & & & & \\
\hline \multicolumn{7}{|c|}{ Calibration } \\
\hline Yield $\left(\mathrm{t} \mathrm{ha}^{-1}\right)$ & 2.18 & 2.07 & 0.90 & 0.24 & 0.85 & 0.98 \\
\hline \multicolumn{7}{|c|}{ Validation } \\
\hline Yield (t ha-1) & 2.18 & 2.45 & 0.99 & 0.10 & 0.99 & 0.99 \\
\hline
\end{tabular}

NRMSE - Normalized root mean squre error; EF - Nash-Sutcliffe model efficiency coefficient; d - Willmott's index of agreement

observed, indicate that the model does not have either great variability or expressive trend. In general, the results are very consistent, because the difference between the yield estimated by the model and the observed yield was only $0.11 \mathrm{t} \mathrm{ha}^{-1}$, indicating that the model underestimated grain yield by only $5 \%$. Lower values of NRMSE and $\mathrm{EF}=0.85$ for AquaCrop simulations indicate good performance of this model. Abrha et al. (2012) found EF values varying between 0.72 and 0.81 when using AquaCrop model to simulate barley yield.

The validation of yield for all irrigation treatments resulted in $\mathrm{R}^{2}=0.99, \mathrm{NRMSE}=0.10 \mathrm{t} \mathrm{ha}^{-1}, \mathrm{EF}=0.99$ and $\mathrm{d}=0.99$. The values of $\mathrm{R}^{2}, \mathrm{~d}$ and $\mathrm{EF}$ close to 1 and NRMSE of $0.10 \mathrm{t} \mathrm{ha}^{-1}$ indicate successful validation of the model, showing that the model was able to accurately simulate soybean grain yield under different irrigation depths. Similar results have been found using the AquaCrop model: Silva et al. (2018), who found $\mathrm{R}^{2}=0.94$ and $\mathrm{d}=0.96$ for the soybean cultivar MSOY $9144 \mathrm{RR}$ and $\mathrm{R}^{2}=0.93$ and $\mathrm{d}=0.99$ for the cultivar TMG $1288 \mathrm{RR}$; García-Vila \& Fereres (2012), for cotton $\left(R^{2}=0.92, d=0.96\right)$, maize $\left(R^{2}=0.99, d=0.99\right)$, potato $\left(R^{2}=0.99, d=0.99\right)$ and sunflower $\left(\mathrm{R}^{2}=0.86, \mathrm{~d}=0.94\right)$; Mabhaudhi et al. (2014) for taro crop $\left(\mathrm{R}^{2}=0.98\right.$ and $\left.\mathrm{d}=0.99\right)$; and Bello \& Walker (2017) for amaranth crop $\left(\mathrm{R}^{2}=0.92\right.$ and $\left.\mathrm{d}=0.91\right)$. These authors also observed that it was difficult for the model to accurately simulate soybean yield under severe water deficit conditions.

The relationships between soybean yields estimated by the model for the different irrigation treatments and the yields observed for calibration and validation are shown in Figures $1 \mathrm{~A}$ and $B$, respectively. In the analysis of the entire set of observed and estimated data, in the calibration process, it is observed that the AquaCrop model showed a good fit to the observed data, with values of $\mathrm{R}^{2}$ and $\mathrm{EF}$ close to one for the treatments for the AquaCrop validation (Figure 1B)

These results indicate once again that the model has better performance in the simulation for the condition without severe water deficit throughout the soybean cultivation cycle and is most accurate for irrigation treatments that did not undergo water deficit in some stage of soybean development. For

Table 2. Yield calibration and validation for the different irrigation treatments

\begin{tabular}{|c|c|c|c|c|c|c|}
\hline \multirow{3}{*}{ Treatments } & \multirow{2}{*}{\multicolumn{2}{|c|}{$\begin{array}{l}\text { Yield (t ha-1) } \\
\text { Calibration }\end{array}$}} & \multirow{3}{*}{$\begin{array}{c}\text { PE } \\
( \pm \%)\end{array}$} & \multirow{2}{*}{\multicolumn{2}{|c|}{$\begin{array}{c}\text { Yield (t ha-1) } \\
\text { Validation }\end{array}$}} & \multirow{3}{*}{$\begin{array}{c}P E \\
( \pm \%)\end{array}$} \\
\hline & & & & & & \\
\hline & Obs. & Sim. & & Obs. & Sim. & \\
\hline T1 - 25\% ETC TC & 1.26 & 1.12 & -10.92 & 0.96 & 1.04 & 8.33 \\
\hline T2 -100\% ETc VS 25\% and ETc RS & 1.86 & 1.86 & 0.25 & 1.56 & 1.63 & 4.42 \\
\hline T3 - 50\% ETC TC & 2.25 & 1.63 & -27.50 & 1.88 & 1.86 & -0.90 \\
\hline T4 - 100\% ETc VS and 50\% ETc RS & 1.85 & 1.86 & 0.36 & 2.44 & 2.40 & -1.80 \\
\hline T5 - 25\% ETc VS and 100\% ETc RS & 2.15 & 2.15 & 0.04 & 2.89 & 2.73 & -5.71 \\
\hline T6 - 50\% ETc VS and $100 \%$ ETc RS & 2.43 & 2.42 & -0.23 & 3.91 & 3.76 & -3.86 \\
\hline T7 - 100\% ETC TC & 3.46 & 3.45 & -0.44 & 3.72 & 3.77 & 1.45 \\
\hline
\end{tabular}

Obs. - Observed; Sim. - Simulated; PE - Prediction error; TC - Thoughout the cycle; VS - Vegetative stages; RS - Reproductive stage 


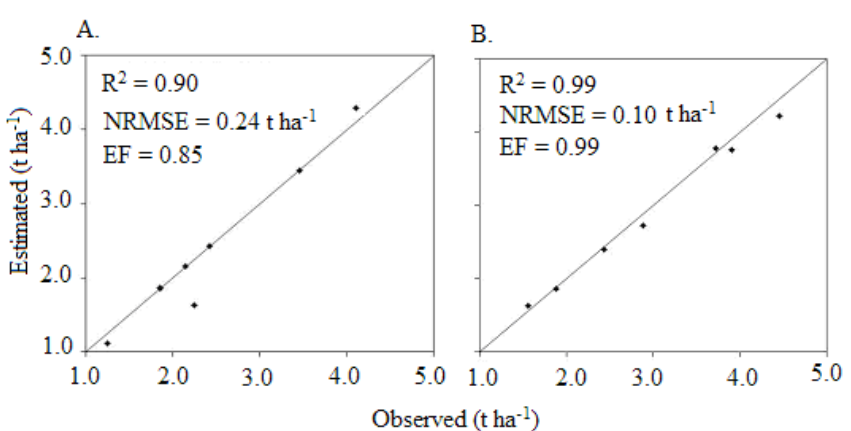

NRMSE - Normalized root mean square error; EF - Nash-Sutcliffe model efficiency coefficient

Figure 1. Estimated and observed values of calibration (A) and validation (B) of the AquaCrop model for the grain yield of TMG 1288 RR soybean for all irrigation treatments

calibration, the model underestimated grain yield for $\mathrm{T} 1$ and T3 (Table 2), probably due to water deficit in the reproductive stage, in which there is greater water demand by the plant. Thus, it can be concluded that the results obtained in the statistical evaluation of AquaCrop calibration are within those reported in applications for soybean, indicating that AquaCrop can be used for predicting yield when adequately calibrated.

Heng et al. (2009) found better performance of the AquaCrop model under mild water stress conditions, whereas under severe water stress conditions the performance of the model is less satisfactory, especially when the stress occurs during the reproductive stage. Stricevic et al. (2011) observed that AquaCrop model underestimated the beet crop yield when the soil was extremely dry. Zeleke et al. (2011) found that AquaCrop model overestimates the yield of canola cultivated under water stress condition, indicating that the simulations of the model are less satisfactory under these conditions, especially when the stress occurred during senescence. Abedinpour et al. (2012) identified that the AquaCrop model predicts maize yield with higher accuracy under conditions of no water deficit and nitrogen deficiency. Xiangxiang et al. (2013), when evaluating the efficiency of the AquaCrop model in estimating wheat yield in China under different irrigation regimes, also found that the model has better yield simulations under wet conditions and less precise simulations under dry conditions.

Regarding validation, the treatment $\mathrm{T} 1$ showed overestimation of simulated yield over the observed yield and the treatments T5 and T6 showed slight underestimation (Table 2). These results also indicate that the model has better performance in the simulation for the condition of no water deficit throughout the soybean cultivation cycle or in only one development stage. Similar results were obtained by Silva et al. (2018) when they calibrated and validated the AquaCrop model to obtain soybean yield under different irrigation depths in the geographic region of Matopiba.

Table 4 presents the $\mathrm{CO}_{2}$ concentration and soybean yield for average medium-term period (2045/2046 and 2055/2056) and long-term period (2075/2076 and 2094/2095), compared with the current scenario, projected by the models HadGEM2-ES and MIROC5 under the scenarios RCP 4.5 and 8.5 in the study area. The scenarios adopted in this study provided different $\mathrm{CO}_{2}$ concentrations for the future climate. For the model HadGEM2-ES, the scenario RCP 4.5 had an increment of $\mathrm{CO}_{2}$ of approximately $160 \mathrm{ppm}$, changing from $378.8 \mathrm{ppm}$ in the current scenario to $536 \mathrm{ppm}$ by the end of the century (2094/2095), with the scenario RCP 4.5. On the other hand, under the scenario RCP 8.5 the increment of $\mathrm{CO}_{2}$ doubled, changing from $378.8 \mathrm{ppm}$ in the current condition to $885.0 \mathrm{ppm}$ in the period of 2094/2095.

All the climate projections assumed, resulting from the simulations with the model from the crop parameters of the treatment with best fit in the calibration, indicated an

Table 4. $\mathrm{CO}_{2}$ concentration and soybean yield ( $\mathrm{ha}^{-1}$ ) estimated by the climate models HadGEM2-ES and MIROC5 under the scenarios RCP 4.5 and RCP 8.5 for the localities of Balsas, MA, Campos Lindos, TO, Baixa Grande do Ribeiro, PI, and Formosa do Rio Preto, BA, Brazil

\begin{tabular}{|c|c|c|c|c|c|}
\hline \multirow{2}{*}{ Periods } & \multirow{2}{*}{ Current } & \multicolumn{2}{|c|}{ Medium term } & \multicolumn{2}{|c|}{ Long term } \\
\hline & & $2045 / 2046$ & $2055 / 2056$ & $2075 / 76$ & $2094 / 2095$ \\
\hline Model/Scenario & & \multicolumn{4}{|c|}{ HadGEM2-ES/RCP 4.5} \\
\hline $\mathrm{CO}_{2}$ concentration (ppm) & 378.8 & 475.0 & 500.0 & 530.0 & 536.0 \\
\hline Balsas, MA & 3.04 & 3.69 & 3.77 & 3.85 & 3.86 \\
\hline Campos Lindos, T0 & 2.86 & 3.64 & 3.77 & 3.82 & 3.84 \\
\hline Baixa Grande do Ribeiro, PI & 2.83 & 3.71 & 3.83 & 3.87 & 3.95 \\
\hline Formosa do Rio Preto, BA & 2.58 & 3.47 & 3.61 & 3.91 & 3.92 \\
\hline Model/Scenario & \multicolumn{5}{|c|}{ MIR0C5/RCP 4.5} \\
\hline Balsas, MA & 3.04 & 3.78 & 3.86 & 3.93 & 3.95 \\
\hline Campos Lindos, T0 & 2.86 & 3.72 & 3.78 & 3.92 & 3.93 \\
\hline Baixa Grande do Ribeiro, PI & 2.83 & 3.72 & 3.92 & 3.99 & 4.02 \\
\hline Formosa do Rio Preto, BA & 2.58 & 3.51 & 3.59 & 3.77 & 3.81 \\
\hline Model/Scenario & \multicolumn{5}{|c|}{ HadGEM2-ES/RCP 8.5} \\
\hline $\mathrm{CO}_{2}$ concentration (ppm) & 378.8 & 516.0 & 575.0 & 720.0 & 885.0 \\
\hline Balsas, MA & 3.04 & 3.81 & 3.88 & 4.21 & 4.41 \\
\hline Campos Lindos, T0 & 2.86 & 3.83 & 4.02 & 4.27 & 4.40 \\
\hline Baixa Grande do Ribeiro, PI & 2.83 & 3.90 & 3.94 & 4.32 & 4.53 \\
\hline Formosa do Rio Preto, BA & 2.58 & 3.70 & 4.15 & 4.45 & 4.73 \\
\hline Model/Scenario & \multicolumn{5}{|c|}{ MIR0C5/RCP 8.5} \\
\hline Balsas, MA & 3.04 & 3.90 & 4.01 & 4.29 & 4.47 \\
\hline Campos Lindos, T0 & 2.86 & 3.83 & 3.92 & 3.71 & 4.41 \\
\hline Baixa Grande do Ribeiro, PI & 2.83 & 3.97 & 4.09 & 4.20 & 4.65 \\
\hline Formosa do Rio Preto, BA & 2.58 & 3.66 & 3.81 & 4.48 & 4.76 \\
\hline
\end{tabular}


increment of soybean grain yield for the period between 2045/2046 and 2094/2095 compared to the current condition.

The predicted increments ranged from 2045/2046 scenario to $2094 / 2095$ scenario from $2.58 \mathrm{t} \mathrm{ha}^{-1}$ to $3.92 \mathrm{t} \mathrm{ha}^{-1}$ in Formosa do Rio Preto, BA, for the model HadGEM2-ES/RCP 4.5 and from $3.72 \mathrm{t} \mathrm{ha}^{-1}$ and $4.02 \mathrm{t} \mathrm{ha}^{-1}$ in Baixa Grande do Ribeiro, PI, for the model MIROC5/RCP 4.5. The models HadGEM2-ES/ RCP 8.5 and MIROC5/RCP 8.5 have produced the highest yield values for the 2094/2095, considering the current scenario.

The MIROC5 model projected higher increments of yield under RCP 4.5, when compared to the current scenario. The yields increased up to $0.91 \mathrm{t} \mathrm{ha}^{-1}$, in Balsas, MA; 1,07 $\mathrm{t} \mathrm{ha}^{-1}$ in Campos Lindos, TO, $1.19 \mathrm{t} \mathrm{ha}^{-1}$ Baixa Grande do Ribeiro, PI, and $1.23 \mathrm{t} \mathrm{ha}^{-1}$ in Formosa do Rio Preto, BA. On the other hand, the HadGEM2-ES, combined with the scenario RCP 8.5, also projected yield increment, but in a more accentuated manner. The yield increased $0.6 \mathrm{tha}^{-1}$ in Balsas, MA, $0.57 \mathrm{t} \mathrm{ha}^{-1}$ in Campos Lindos, TO, 0.63 tha $^{-1}$ in Baixa Grande do Ribeiro, PI and $1.03 \mathrm{t} \mathrm{ha}^{-1}$ in Formosa do Rio Preto, BA.

It was verified by the projections that the model MIROC5 has the characteristic of showing rainier conditions than the HadGEM2-ES, but even with the reduction of rainfall throughout the soybean cultivation cycle, observed in both models, with reduction in total rainfall, varying from 611 to $1250 \mathrm{~mm}$, combined with the increments of temperature and $\mathrm{CO}_{2}$, it may have contributed positively to the yield. According to Doorenbos \& Kassam (1979), in order to obtain high yield, the water needs of the soybean crop must be between 450 and $850 \mathrm{~mm}$ per cycle, depending on the climate, management and duration of its growth period. Thus, it is suggested that this condition may have contributed to the increase in the yield estimated by these two models, which together with the increase of air temperature and $\mathrm{CO}_{2}$ in the atmosphere favored the observed condition.

C3 plants, such as soybean, positively respond to the direct effects of $\mathrm{CO}_{2}$ fertilization. Castillo (2016), analyzing the effects of changes in temperature, rainfall and atmospheric concentration of $\mathrm{CO}_{2}$ on the water demand and grain yield of soybean in the Potiribu River basin, RS, Brazil, verified increase in yield in comparison with the historical mean and attributed this condition mainly to the increase in the atmospheric concentration of $\mathrm{CO}_{2}$. On the other hand, Abrha et al. (2012), when investigating the impact of a hypothetical climate and $\mathrm{CO}_{2}$ scenarios in South America, found that the combined effect of doubling of $\mathrm{CO}_{2}$ and the increments of $2{ }^{\circ} \mathrm{C}$ in temperature and $10 \%$ in rainfall increase maize yield.

\section{Conclusions}

1. The validation of the AquaCrop model indicate that it can be used to predict soybean grain yield with an acceptable accuracy in the prediction of climate change scenarios in the Matopiba geographic region.

2. The AquaCrop model underestimates soybean grain yield under severe water stress conditions throughout the soybean cultivation cycle and estimated high yield when deficit irrigation was applied only in the vegetative stage.

3. Soybean grain yield in the Matopiba geographic region, projected by AquaCrop through the models HadGEM2-ES and
MIROC5 and under the scenarios of stabilization (RCP 4.5) and progression (RCP 8.5), increased over the four seasons analyzed. The increase in $\mathrm{CO}_{2}$ concentration and temperature, projected by the climate models, contributes to the increase of soybean yield by the end of this century.

\section{Literature Cited}

Abedinpour, M.; Sarangi, A.; Rajput, T. B. S.; Singh, M.; Pathak, H.; Ahmad, T. Performance evaluation of AquaCrop model for maize crop in a semi-arid environment. Agricultural Water Management, v.110, p.55-66. 2012. https://doi.org/10.1016/j. agwat.2012.04.001

Abi Saab, M. T.; Todorovicb, M.; Albrizioc, R. Comparing AquaCrop and CropSyst models in simulating barley growth and yield under different water and nitrogen regimes. Does calibration year influence the performance of crop growth models? Agricultural Water Management, v.147, p.21-33, 2014. https:// doi.org/10.1016/j.agwat.2014.08.001

Abrha, B.; Delbecque, N.; Raes, D.; Tsegay, A.; Todorovic, M.; Heng, L.; Vanutrecht, E.; Geerts, S.; García-Vila, M.; Deckers, S. Sowing strategies for barley (Hordeum vulgare L.) based on modelled yield response to water with aquacrop. Experimental Agriculture, v.48, p.252-271, 2012. https://doi.org/10.1017/S0014479711001190

Allen, R. G.; Pereira, L. S.; Raes, D.; Smith, M. Crop evapotranspiration: Guidelines for computing crop water requirements. Rome: FAO. 1998. 300p. Irrigation and Drainage Paper, 56

Araya, A.; Habtub, S.; Hadguc, K. M.; Kebedea, A.; Dejened, T. Test of AquaCrop model in simulating biomass and yield of water deficient and irrigated barley (Hordeum vulgare). Agricultural Water Management, v.97, p.1838-1846, 2010. https://doi. org/10.1016/j.agwat.2010.06.021

Baumhardt, R. L.; Staggenborg, S. A.; Gowda, P. H.; Colaizzi, P. D.; Howell, T. A. Modelling irrigation management strategies to maximize cotton lint yield and water use efficiency. Agronomy Journal, v.101, p.460-468, 2009. https://doi.org/10.2134/ agronj2008.0041xs

Bello, Z. A.; Walker, S. Evaluating AquaCrop model for simulating production of amaranthus (Amaranthus cruentus) a leafy vegetable, under irrigation and rainfed. Agricultural and Forest Meteorology, v.247, p.300-310, 2017. https://doi.org/10.1016/j. agrformet.2017.08.003

Bellouin, N.; Rae, J.; Jones, A.; Johnson, C.; Haywood, J.; Boucher, O. Aerosol forcing in the Climate Model Intercomparison Project (CMIP5) simulations by HadGEM2-ES and the role of ammonium nitrate. Journal of Geophysical Research Atmospheres, 116 (D20). D20206. ISSN 0148-0227. 2011. https:// doi.org/10.1029/2011JD016074

Brasil. Ministério da Agricultura, Pecuária e Abastecimento. Economia e emprego. Brasil lança plano agropecuário para a região do Matopiba. 2015. Available at: <http://www.brasil.gov.br/ economia-e-emprego/2015/05/brasil-lanca-plano-agropecuariopara-regiao-do-matopiba>. Accessed in: Fev. 2016.

Castillo, A. C. Efeito das mudanças climáticas sobre a demanda de água para irrigação e o rendimento de grãos da cultura da soja na bacia do Rio Potiribu, Rio Grande do Sul. Porto Alegre: UFRGS, 2016. 79p. Tese Doutorado

Doorenbos, J.; Kassam, A. H. Yield response to water. Rome: FAO, 1979. 235p. Irrigation and Drainage Paper, 33 
Fagundes, J. D.; Paula, G. M. de.; Lago, I. Â.; Streck, N. A.; Bisognin, D. A. Aquecimento global: Efeitos no crescimento, no desenvolvimento e na produtividade de batata. Ciência Rural, v.40, p.1464-1472, 2010. https://doi.org/10.1590/S0103-84782010005000091

FAO - Food and Agriculture Organization of the United Nations. ETo Calculator. Version 3.2. Rome: FAO, 2012. 38p.

García-Vila, M.; Fereres, E. Combining the simulation crop model AquaCrop with an economic model for the optimization of irrigation management at farm level. European Journal of Agronomy, v.36, p.21-31, 2012. https://doi.org/10.1016/j.eja.2011.08.003

Heng, L. K.; Hsiao, T.; Evett, S.; Howell, T.; Steduto, P. Validating the FAO AquaCrop model for irrigated and water deficient field maize. Agronomy Journal, v.101, p.488-498. 2009. https://doi. org/10.2134/agronj2008.0029xs

IPCC, 2014: Climate change 2014: Synthesis Report. Contribution of Working Groups I, II and III to the Fifth Assessment Report of the Intergovernmental Panel on Climate Change [Core Writing Team, Pachauri, R.K.; Meyer, L.A. (eds.)]. Geneva: IPCC, 151p.

Karunaratne, A. S.; Azam-Ali, S. N.; Izzi, G.; Steduto, P. Calibration and validation of FAO-AquaCrop model for irrigated and water deficient Bambara groundnuts. Experimental Agriculrurae, v.47, p.509-527, 2011. https://doi.org/10.1017/S0014479711000111

Mabhaudhi, T.; Modia, A. T.; Beletseb, Y. B. Parameterisation and evaluation of the FAO-AquaCrop model for a South African taro (Colocasia esculenta L. Schott) landrace. Agricultural and Forest Meteorology, v.192-193, p.132-139, 2014. https://doi. org/10.1016/j.agrformet.2014.03.013

Paredes, P.; Wei, Z.; Liu, Y.; Xu, D.; Xin, Y.; Zhang, B.; Pereira, L. S. Performance assessment of the FAO AquaCrop model for soil water, soil evaporation, biomass and yield of soybeans in North China Plain. Agricultural Water Management, v.152, p.57-71, 2015. https://doi.org/10.1016/j.agwat.2014.12.007
Raes, D.; Steduto, P.; Hsiao, T. C.; Fereres, E. AquaCrop: The FAO crop model to simulate yield response to water. II. Main algorithms and software description. Agronomy Journal, v.101, p.438-447, 2009. https://doi.org/10.2134/agronj2008.0140s

Silva, V. de P. R.; Silva, R. A. e; Maciel, G. F.; Braga, C. C.; Silva Júnior, J. L. C. da; Souza, E. P. de; Rodrigues, R. S.; Silva, M. T.; Holanda, R. M. de. Calibration and validation of the AquaCrop model for the soybean crop grown under different levels of irrigation in the Motopiba region, Brazil. Ciência Rural, v.48, p.1-8, 2018. https:// doi.org/10.1590/0103-8478cr20161118

Steduto, P.; Hsiao, T. C.; Raes, D.; Fereres, E. AquaCrop-The FAO crop model to simulate yield response to water: I. Concepts and underlying principles. Agronomy Journal, v.101, p.426-437, 2009. https://doi.org/10.2134/agronj2008.0139s

Steduto, P.; Raes, D.; Hsiao, T. C.; Fereres, E. AquaCrop: Concepts, rationale and operation. In: Crop yield response to water. Rome: FAO, 2012. Irrigation \& Drainage paper vol. 66

Stricevic, S.; Cosic, M.; Djurovic, N.; Pejic, B.; Maksimovic, L. Assessment of the FAO AquaCrop model in the simulation of rainfed and supplementally irrigated maize, sugar beet and sunflower. Agricultural Water Management, v.98, p.1615-1621, 2011. https://doi.org/10.1016/j.agwat.2011.05.011

Xiangxiang, W.; Quanjiu, W.; Jun, F.; Qiuping, F. Evaluation of the AquaCrop model for simulating the impact of water deficits and different irrigation regimes on the biomass and yield of winter wheat grown on China's Loess Plateau. Agricultural Water Management, v.129, p.95-104, 2013. https://doi.org/10.1016/j. agwat.2013.07.010

Zeleke, K. T.; Luckett, D.; Cowley, R. Calibration and testing of the FAO AquaCrop model for canola. Agronomy Journal, v. 103, p.1610-1618, 2011. https://doi.org/10.2134/agronj2011.0150 